taken in the alignment of the microscope and the cleaning of the quartz chamber.

Copies of this instructional film (screening time about $4 \mathrm{~min}$.) can now be hired from the Scottish Central Film Library, 2 Newton Place, Glasgow, C.2.

\section{CONTROL OF ST. JOHN'S WORT IN AUSTRALIA*}

By DR. A. D. IMMS, F.R.S.

$\mathrm{F}^{1}$ IVE species of St. John's wort (Hypericum) occur in Australia - mainly in Victoria and New South Wales. These species are $H$. perforatum L., $H$. androscmum L., $H$. calycium L., $H$. gramineum Forst. and $H$. japonicum Thunb. The first-named is by far the most widespread and the chief pest. Between 250,000 and 400,000 acres of land in Victoria and very large areas in New South Wales are in. fested with $H$, perforatum, and it also occurs in South Australia, Tasmania and Western Australia. The species was introduced in 1870 in Victoria, and since it occurs chiefly in hill and plateau country it is one of the most injurious of Australian weeds. Growing thickly, it eliminates all low-growing vegetation including pasture grasses, and some of the areas covered by the weed have had to be abandoned. It is, furthermore, poisonous to stock.

Several methods of controlling $H$. perforatum have been adopted in Australia and some success has been achieved by the application of common salt at the rate of ten, or more, tons to the acre. This treatment, however, is too expensive for general use although it is employed in Victoria to keep the roadsides free from the weed. The possibility of its repression by insects was first taken into account in 1917, and certain species of Hypericum-feeding insects were introduced in succeeding years from England. These were certain beetles of the family Chrysomelidæ- the species Chrysolina varians Schell., $C$. brunsvicensis Grow. and $C$. hyperici Forst., all of which are leaffeeders. The Geometrid moths Anaitis efformata Guen. and $A$. plagiata L., the larvæ of which feed on the foliage of Hypericum, were also introduced from England. None of these appeared to become established and the primary cause of the failure of most of them appeared to be climatic.

Attention was then directed to Hypericum insects in southern France, where field observations showed that a high degree of control is achieved in particular places by the Buprestid beetle Agrilus hyperici Creutz. and the Chrysomelid beetle Chrysolina gemellata Rossi. Supplies of both these species were shipped to Australia in 1939 and 1940. The species Chrysolina hyperici disappeared for some years after its libera. tion, but has since been found in large numbers and is now firmly established in many areas.

None of the other species of insects introduced from England has apparently become established. While $C$. hyperici now occurs in many localities, as yet it only occupies a mere fraction of the total Hypericum area of Australia. C. gemellata became very readily established and spread and the Agrilus hyperici gives great promise and is increasing rapidly in several of the areas where its original liberation took place in 1939 and 1940. At present, however, the area actually covered by these last two species * The Entomological Control of St. John's Wort (Hypericum per-
foratum L.) by Frank Wilson. Bull. No. I69 Council for Scientiflc and Industrial Research (Melbourne, 1943). is even smaller than that covered by $C$. hyperici. There is every prospect that the three species named will eventually occur in all the St. John's wort areas. Their present limited distribution is naturally to be expected because they have only been introduced during a brief period. The retrogression of the weed where $C$. hyperici is numerous and the continuous increase in the numbers of this insect, together with the ease with which the other species $(C$. gemellata and $A$. hyperici) have become established, give ground for confidence that a useful degree of control of the weed will, in time, be achieved.

\section{STRUCTURE, FUNCTION AND SYNTHESIS OF POLYSACCHARIDES*}

$\triangle$ NEW chemical synthesis of cellobiose by a A simple and direct method has been accomplished by Stacey and Gilbert. The structure of the repeating unit in cellulose is therefore well established, and the microbiological synthesis of the polysaccharide was achieved by Hibbert. Starch, another functional material of the plant, is recognizable as two structural types of polysaccharide: amylose giving the deep blue coloration with iodine and representing about 25 per cent of natural starch, and amylopectin, the remaining 75 per cent, giving a reddish-blue colour. Amylose, synthesized both by plant and muscle phosphorylase, is represented as a continurous chain of maltose units and this is completely hydrolysed to maltose by $\beta$-amylase. Amylopectin is also composed of maltose units in shorter chains which are united as a laminated or branched-chain structure, and this is hydrolysed in stages to maltose and various dextrins. The factor responsible for the synthesis of amylopectin has not yet been isolated, but attempts have been made in this direction. Products related to amylopectin have been obtained by Dr. Peat, but their identity is not yet established.

Many of the specific and somatic bacterial polysaccharides contain amino-glucose and uronic acids as constituent units. The constitutional relationship of these polysaccharides is only partly revealed, although some synthetic analogues which are bioses are seen also to have antigenic properties. Structurally related to these are the polysaccharides produced by non-pathogenic organisms such as Rhizobia; and the plant gums which also contain uronic acid groups.

Heparin, the blood anti-coagulant factor of liver, contains glucosamine and glucuronic acid units together with acetyl and sulphate residues. The chondroitin of cartilege is similar in the composition of its individual units except that galactosamine (or talosamine) replaces glucosamine.

The synthesis of the levans by enzymes has been frequently reported; their constitution is now established, as is also that of the dextrans from Penicillium luteum and Leuconostoc dextranicum. These are $1: 6$-glucopyranose polymers.

$B$. welchii, the gas gangrene organism, is convertible into a Gram-negative form by sodium cholate ex. traction. The Gram-positive character can be restored by combination with the magnesium salt of ribonucleic acid. The constitution of both this acid and desoxy-ribonucleic acid is partly revealed by the recognition of ribo- and desoxyribofuranose units, the mode of combination of which, whether single or linked units, is not yet known.

* Substance of the Bakerian Lecture delivered before the Royal Society by Prof. W. N. Haworth, F.R.S., on June 15. 